\title{
First data on spiders and harvestmen (Arachnida: Aranei, Opiliones) from Karaginski Island, Eastern Koryakia, Kamchatka Peninsula
}

\author{
Первые данные о пауках и сенокосцах (Arachnida: Aranei, \\ Opiliones) острова Карагинский, Восточная Корякия, Камчатка
}

\author{
Yuri M. Marusik ${ }^{1,2}$ \& Olga A. Khrulyova ${ }^{3}$ \\ Ю.М. Марусик ${ }^{1,2}$, О.А. Хрулёва \\ ${ }^{1}$ Institute for biological problems of the North, FEB RAS, Portovaya Str. 18, Magadan 685000, Russia. E-mail: yurmar@mail.ru
2 Zoological Museum, University of Turku, FI-20014 Turku, Finland.
${ }^{3}$ Institute of Ecology and Evolution RAS, Leninsky pr. 33, Moscow 119071, Russia. E-mail: 1sdc@mail.ru
${ }^{1}$ Институт биологических проблем Севера ДВО РАН, ул. Портовая 18, Магадан 685000, Россия.
${ }^{3}$ Институт проблем экологии и эволюции РАН, Ленинский пр. 33, Москва 119071, Россия.
}

KEY WORDS: Northeast Asia, Far East Asia, new record, Kamchatka Province.

КЛЮЧЕВЫЕ СЛОВА: Северо-Восток Азии, Дальний Восток, новая находка, Камчатский край.

\begin{abstract}
The spider and harvestman faunas of Karaginski Island were studied for the first time. 56 species of spiders and one species of harvestman are reported from the island. Of these, 26 spider species are new to Koryakia and 9 of them are new for the entire Kamchatka Province. The total number of spider species found in Koryakia now totals 117.
\end{abstract}

РЕЗЮМЕ. Впервые приводятся данные по фауне пауков и сенокосцев острова Карагинский. На острове отмечено 56 видов пауков и 1 вид сенокосцев. 26 видов пауков являются новыми для Корякии, 9 видов - для Камчатской области в целом. Общее число видов пауков, отмеченных в Корякии, достигло 117.

\section{Introduction}

The arachnid fauna of Koryakia is one of the most poorly studied arachnofaunas of Russia. Only six species of spiders were known from the region before 2010 [Marusik et al., 2010]. The fauna of the whole Kamchatka Province is also poorly-studied, with approximately 220 species reported [cf. Mikhailov, 2002; Marusik et al., 2010]. The number of spider species known from the Kamchatka Province is half of that in the Sakhalin Area and even smaller when compared to that known for the Magadan Area [cf. Marusik et al., 2010].

Recently, the junior author had an opportunity to collect terrestrial invertebrates on Karaginski Island, which administratively belongs to Koryakia. It is located close to the northeastern part of the Kamchatka Peninsula at $59^{\circ} \mathrm{N}$ latitude in the Bering Sea. The area of the island is $2000 \mathrm{~km}^{2}$ and its highest elevation is over $900 \mathrm{~m}$. Karaginski Island is situated in the zone of the island permafrost, and its climate is rather severe (the average February temperature is $-15^{\circ} \mathrm{C}$, the temperature of August does not exceed $12^{\circ} \mathrm{C}$ ). According to the scheme of phytogeographic division, Karaginski Island, together with other northern regions of Kamchatka, belongs to the Beringian forest-tundra Province. About half of its territory is occupied by different so-called tundra communities; elfin woodland formations also have a broad distribution on this island [Barkalov et al., 1986]. The aim of this paper is to provide a list of spiders and harvestmen found on the island. All species were found on the island for the first time.

\section{Material and methods}

All material was collected between July 13 and 29, 2008 in a small area (ca. $2 \mathrm{~km}^{2}$ ) in the middle part of the western shore near Gnunvayam River mouth $\left(58^{\circ} 53^{\prime} \mathrm{N} 163^{\circ} 47^{\prime} \mathrm{E}\right)$. The study area included the following habitat types: littoral, slopes and plain parts of the sea terrace and bedrock shore, and also river valley close to its mouth. The most common habitats in the region were the so-called shrub tundra communities with some Pinus pumila on the plain parts of the sea terrace (dominant plants: Pinus pumila, Arctous alpina, Ledum decumbens, Empetrum nigrum, Vaccinium minus and Betula exilis), and different types of meadows. In addition to these, we studied moist herb-moss communities in hollows, river and sea gravel shores, alder stands and some other habitats. Most of the material was collected by pitfall trapping (1094 trap days) and by sweeping with an entomological sweep-net. 


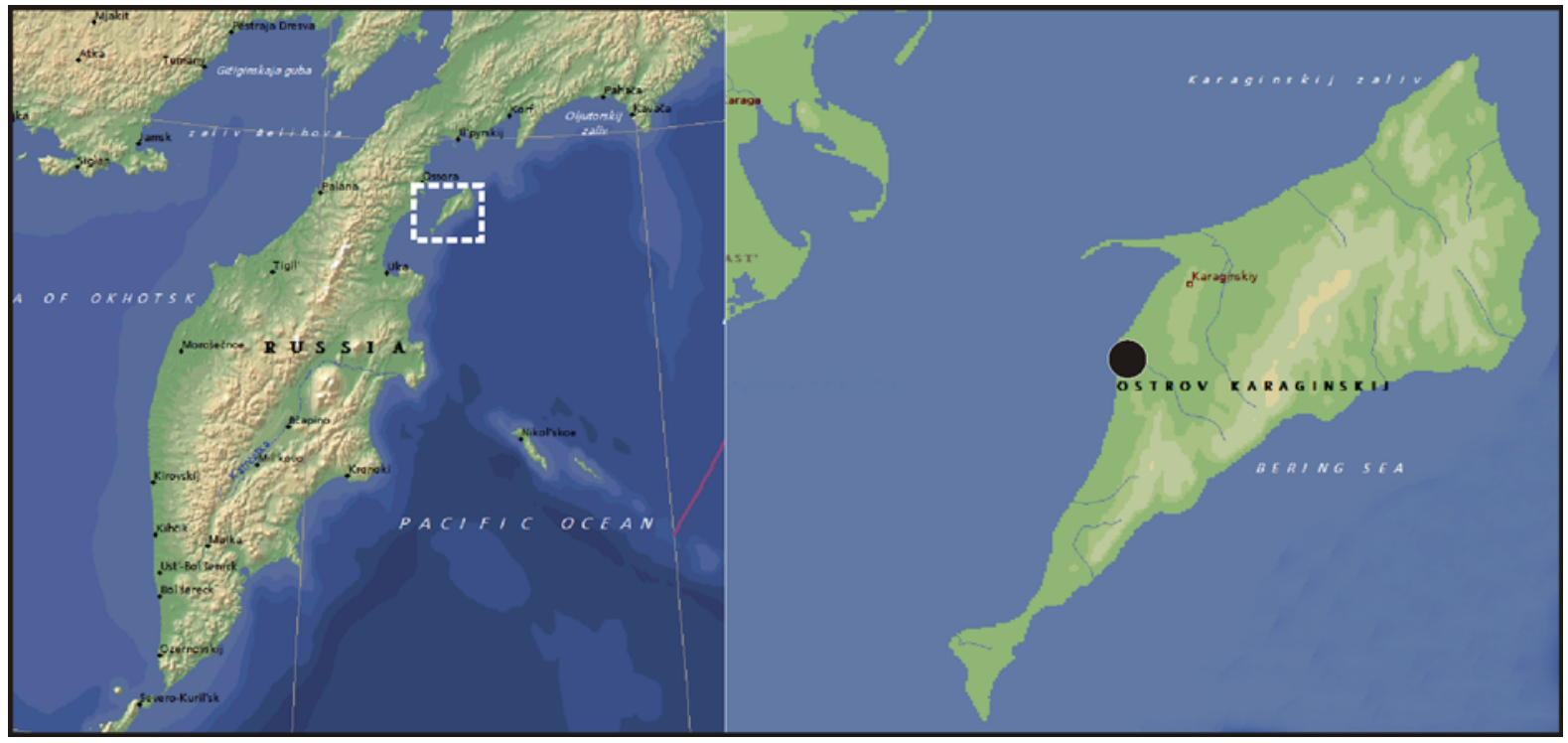

Map 1. Map of Kamchatka Province and Karaginski Island. Square indicates Karaginski Island and dot indicates collecting site.

Карта 1. Камчатский край и остров Карагинский. Квадратом выделен остров Карагинский. Точкой показано место сборов.

The material treated herein will be deposited in the Zoological Museum of the Moscow State University.

Species new to the fauna of Koryakia are marked with an asterisk. Two asterisks means that the species is a new record for the entire Kamchatka Peninsula. In the species survey we provide information about all morphospecies, including those unidentifiable to species level.

\section{Species survey}

\section{Order ARANEI}

Family Araneidae (3)

Araneus yukon Levi, 1971

COMMENTS. This species was recently reported from Kamchatka and Western Koryakia for the first time [Marusik et al., 2010]. The species is a herb dweller. It was found in several habitats on the island (cf. Table 1). It has an East Siberian - northwestern Nearctic range.

Araniella proxima (Kulczyński, 1885)*

This species was described from the environs of Petropavlovsk-Kamchatski and has a Holarctic range. Although it has a broad range it was hitherto unknown from Koryakia.

Larinioides cornutus (Clerck, 1757)*

COMMENTS. Although this species has a circumHolarctic polyzonal range, it was hitherto unknown from Koryakia.

\section{Family Clubionidae (1)}

\section{Clubiona sp.}

COMMENTS. Only one unidentifiable juvenile specimen was found on the island.

\section{Family Dictynidae (1)}

Hackmania prominula (Tullgren, 1948)**

COMMENTS. This species has a trans-Palaearcticnorthwest Nearctic range. It was hitherto unknown from Koryakia or Kamchatka. This species is a litter dweller, all specimens were found in one habitat - shrubby tundra community with Pinus pumila.

\section{Family Gnaphosidae (4)}

\section{Gnaphosa microps Holm, 1939**}

COMMENTS. Although this species has a circumHolarctic range it was hitherto unknown from Koryakia and the Kamchatka Peninsula. This species was found in several habitats.

Haplodrassus moderatus (Kulczyński in Chyzer et Kulczyński, 1897)*

COMMENTS. This species has a trans-Palaearctic range and was already known from the Kamchatka Peninsula (Kronotskoye Lake) under the name Drassodes simplex Kulczyński, 1926. The two names remain to be formally synonymised. This species was hitherto unknown from Koryakia. All eight specimens were found in one habitat — shrubby tundra community with Pinus pumila.

\section{Haplodrassus soerenseni (Strand, 1900)}

COMMENTS. This species was already known from Western Koryakia [Marusik et al., 2010] but the record was uncertain. The reason for doubt was that only females had been collected. In the new material studied both sexes are represented. The record from Karaginsky Island is the easternmost locality in the known range of this species. 
Table 1. Spatial distribution of spiders and harvestmen on Karaginski Island. Таблица 1. Особенности стациальной приуроченности пауков и сенокосцев на о-ве Карагинский.

\begin{tabular}{|c|c|c|c|c|c|c|c|c|}
\hline Species & $\begin{array}{l}\frac{0}{0} \\
\frac{0}{0} \\
\frac{0}{0} \\
\frac{0}{0} \\
\frac{0}{n}\end{array}$ & 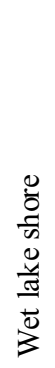 & 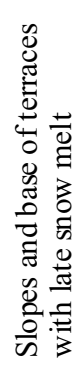 & 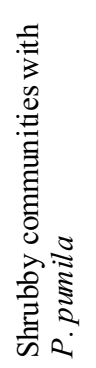 & 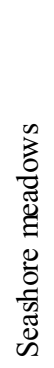 & 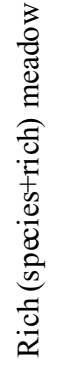 & 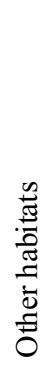 & 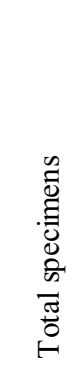 \\
\hline Araneus yukon & - & 2 & - & - & - & 3 & 5 & $100^{70}$ \\
\hline Araniella proxima* & - & 1 & - & - & - & 2 & - & $30^{2}+$ \\
\hline Larinioides cornutus* & - & 1 & - & - & 6 & - & 2 & $70^{7}+9$ \\
\hline Clubiona sp. & - & - & - & - & 1 & - & - & $1 \mathrm{j}$ \\
\hline Hackmania prominula** & - & - & - & 8 & - & - & - & $80^{7}$ \\
\hline Gnaphosa microps ** & - & - & 2 & 3 & - & 5 & - & $100^{12}$ \\
\hline Haplodrassus moderatus* & - & - & - & 8 & - & - & - & $80^{7}$ \\
\hline Haplodrassus soerenseni & - & - & - & 1 & - & - & 6 & $70^{7}+$ \\
\hline Micaria pulicaria* & - & - & - & - & 1 & - & 1 & $20^{7}$ \\
\hline Hahnia ononidum $* *$ & - & - & - & 2 & - & - & 1 & $30^{7}$ \\
\hline Agnyphantes expunctus* & - & - & - & 1 & - & 1 & - & 29 \\
\hline Bathypahntes eumenis & - & - & 2 & 5 & - & - & - & 79 \\
\hline Bathypahntes humilis* & - & 2 & - & - & - & 1 & - & $30^{2}+$ \\
\hline Bathyphantes pogoinias & - & - & 1 & - & - & - & - & $10^{7}$ \\
\hline Dactylopisthes video* & 9 & - & - & - & - & - & - & $90^{7}+9$ \\
\hline Dicymbium libidinosum & - & - & 1 & - & 1 & - & - & 29 \\
\hline Diplocentria bidentata & - & - & 2 & 1 & - & - & - & $30^{r}$ \\
\hline Dismodicus alticeps* & - & - & - & - & 1 & - & - & 19 \\
\hline Erigone cristatopalpus** & 4 & - & - & 1 & - & - & - & $50^{7}+$ \\
\hline Estrandia grandeva & - & - & - & 1 & - & - & - & $1 \mathrm{j}$ \\
\hline Gnathonarium sp. & - & 1 & - & - & 8 & - & - & $9+$ \\
\hline Hilaira herniosa & - & - & - & 1 & - & - & - & $10^{7}$ \\
\hline Horcotes strandi & - & - & 3 & - & - & - & - & $30^{7}$ \\
\hline Hybauchenidium gibbosum & - & 16 & - & - & 12 & 1 & 5 & $34+$ \\
\hline Kaestneria anceps & - & 5 & - & 3 & 3 & - & 3 & $140^{7}+$ \\
\hline Lepthyphantes luteipes & - & - & - & 1 & - & - & - & 19 \\
\hline Macrargus multesimus* & - & - & 2 & - & - & - & - & 29 \\
\hline Microlinyphia pusilla & - & - & - & 1 & - & - & - & 19 \\
\hline Minyrioloides affine & - & 1 & 3 & - & - & 5 & - & $90^{7}+9$ \\
\hline Oreoneta magaputo** & - & - & 21 & $\overline{-}$ & - & - & - & $210^{7}$ \\
\hline Oreonetides vaginatus & - & - & 10 & - & - & - & - & $100^{7}+$ \\
\hline Oryphantes bipilis & - & - & 25 & - & - & - & - & $250^{7}+$ \\
\hline Pelecopsis mengei** & - & - & 1 & - & - & - & - & 19 \\
\hline Phlattothrata parva & - & - & 7 & - & - & - & - & $70^{x}$ \\
\hline Porrhomma montanum & - & - & 1 & - & - & - & - & $10^{7}$ \\
\hline Praestigia kulczynskii & - & - & - & 1 & 7 & - & 1 & 9 9 \\
\hline Savignia birostra* & - & 1 & - & - & - & - & - & 19 \\
\hline Stemonyphantes sibiricus & - & - & - & 3 & 1 & - & 3 & $70^{7}+9$ \\
\hline
\end{tabular}


Table 1 (continuing).

Таблица 1 (продолжение).

\begin{tabular}{|c|c|c|c|c|c|c|c|c|}
\hline Styloctetor lehtineni** & 2 & - & - & - & - & - & - & $20^{7}$ \\
\hline Tenuiphantes mengei* & - & - & - & - & - & 1 & - & 19 \\
\hline Tmeticus tolli* & - & - & - & - & 1 & - & - & 19 \\
\hline Walckenaeria cuspidata & - & - & 5 & - & 1 & - & - & 6 우 \\
\hline Walckenaeria karpinskii & - & - & - & 1 & - & - & - & 19 \\
\hline Wubanoides fissus* & - & - & - & 5 & - & - & 1 & $60^{7}+$ \\
\hline Alopecosa aculeta* & - & - & - & 3 & 1 & 2 & - & $60^{9}+$ \\
\hline Pardosa aff prosaica* & 17 & - & - & - & - & - & - & 179 \\
\hline Pardosa atrata* & - & 25 & - & - & 1 & 1 & - & $270^{2}+$ \\
\hline Pardosa palustris * & - & 14 & 31 & 40 & 110 & 14 & 103 & $3120^{7}+$ \\
\hline Pardosa riparia & - & - & 1 & 5 & - & 8 & $\overline{-}$ & $140^{7}+$ \\
\hline Tibellus maritimus & - & - & - & - & - & 2 & 2 & $40^{7}+$ \\
\hline Siticus floricola** & - & - & - & - & - & - & 1 & $10^{x}$ \\
\hline Tetragnatha extensa & - & 2 & 2 & 41 & 6 & 10 & 2 & $630^{7}+9$ \\
\hline Enoplognatha caricis & - & - & - & - & - & - & 1 & $10^{7} \& j$ \\
\hline Robertus sp. & - & - & - & - & - & 1 & - & $1 \mathrm{j}$ \\
\hline Ozyptila trux** & - & - & - & - & - & 2 & 2 & $40^{x}$ \\
\hline Xysticus britcheri & - & - & - & 6 & 3 & 2 & 4 & $150^{7}+$ \\
\hline Mitopus morio & - & 4 & 123 & 217 & 117 & 77 & 143 & $681 \mathrm{j}$ \\
\hline
\end{tabular}

Note. * Species is new to Koryakia; ** species is new to Kamchatka Province.

Micaria pulicaria (Sundevall, 1831)*

COMMENTS. Although this species has a circumHolarctic range it was hitherto unknown from Koryakia.

Family Hahniidae (1)

Hahnia ononidum (Simon, 1875)**

COMMENTS. Although this species is widespread and common throughout its circum-Holarctic range it was hitherto unknown from Koryakia and Kamchatka. It is a litter dwelling species.

Family Linyphiidae (34) $1875)^{*}$

Agnyphantes expunctus (O. Pickard-Cambridge,

COMMENTS. This species has a trans-Palaearctic range and had previously been recorded from the Kamchatka Peninsula, but not from Koryakia.

Bathyphantes eumenis (L. Koch, 1879)

COMMENTS. This species has an almost circumHolarctic range and had previously been recorded from both Kamchatka and Koryakia.

Bathyphantes humilis (L. Koch, 1879)*

COMMENTS. This species has a Siberian range and had previously been recorded from Kamchatka, but not from Koryakia.

Bathyphantes pogoinias Kulczyński, 1885

COMMENTS. This species was described from Kamchatka Peninsula and from western Koryakia. It is restricted to Beringia and occurs in north Sakhalin and the Kuril Islands, northern Cisokhotia, Kamchatka and Alaska.

Dactylopisthes video (Chamberlin et Ivie, 1947)*

COMMENTS. This species has a Siberio - northwest Nearctic range. It had previously been recorded from the Kamchatka Peninsula, but not from Koryakia. All specimens were collected among stones on the pebbly seashore.

Dicymbium libidinosum (Kulczyński, 1926)

COMMENTS. This species was described from eastern Kamchatka and occurs throughout Siberia.

Diplocentria bidentata (Emerton, 1882)

COMMENTS. The species has a circum-Holarctic range and had previously been recorded from Kamchatka and Koryakia.

Dismodicus alticeps Chamberlin et Ivie, 1947*

COMMENTS. This species has an east Siberio Nearctic range and had previously been recorded from Kamchatka, but not from Koryakia.

Erigone cristatopalpus Simon, 1884?**

COMMENTS. According to Tanasevitch [2011] the species has a Holarctic range. Tanasevitch [2011] synonymised three species with it: E. simillima Keyserling, 1886, E. zographica Crosby \& Bishop, 1928 and E. viabilis Chamberlin \& Ivie, 1933. In our opinion this synonymy is questionable, due to the variation 
in the figures that exist for these species. If the synonymy is correct then E. cristatopalpus has a very unusual distribution range: highlands of Central Europe, Magadan Area, Commander Islands, and the Nearctic. The status of the four species requires further investigations involving molecular studies.

Estrandia grandeva (Keyserling, 1886)

COMMENTS. This species has a circum-Holarctic range and had previously been recorded from Kamchatka and Koryakia.

\section{Gnathonarium sp.}

COMMENTS. We have several females that may belong to one or even two different species, but due to the lack of proper revision of this genus our specimens can not be identified to species level. So far, only one species of Gnathonarium has been recorded from Koryakia: G. taczanowskii (O.Pickard-Cambridge, 1873) [cf. Marusik et al., 2010]. Another two species are known from southern Kamchatka: G. suppositum (Kulczyński, 1885) and G. dentatum (Wider, 1834).

Hilaira herniosa (L. Koch, 1879)

COMMENTS. The species has a circum-Holarctic range and had previously been recorded from Kamchatka and Koryakia.

Horcotes strandi (Sytshevskaja, 1935)

COMMENTS. This species was described from Kamchatka, but was hitherto unknown from Koryakia. It has a circum-Holarctic range.

Hybauchenidium gibbosum (Soerensen, 1898)

COMMENTS. This species has a Siberio-Nearctic range and had previously been recorded from western Koryakia. It is one of the most common species collected on the island.

Kaestneria anceps (Kulczyński, 1885)

COMMENTS. This species was described from Kamchatka and has a Siberio-Nearctic range. It had previously been recorded from western Koryakia. In the study area it was found in a few different habitats.

Lepthyphantes luteipes (L. Koch, 1879)

COMMENTS. This species has an east Palaearctic range and had previously been recorded from western Koryakia.

Macrargus multesimus (O. Pickard-Cambridge, $1875)^{*}$

COMMENTS. This species has a circum-Holarctic range. It had previously been recorded from the Kamchatka Peninsula, but not from Koryakia.

Microlinyphia pusilla (Sundevall, 1830)

COMMENTS. This species has a circum-Holarctic range. It had previously been recorded from the Kamchatka Peninsula and from western Koryakia.
Minyrioloides affine (Schenkel, 1930)

COMMENTS. This species was described from Kamchatka and was recently recorded from western Koryakia [Marusik et al., 2010]. Tanasevitch [2011] synonymised this species with $M$. trifrons (O. PickardCambridge, 1863), but we follow Holm [1945] who demonstrated clear differences in the embolic divisions of the two species.

Oreoneta magaputo Saaristo et Marusik, 2004**

COMMENTS. This species has a Siberio - west Nearctic range. Although it had previously been recorded to both the east and west of the Kamchatka Peninsula it was hitherto unknown from Kamchatka Province. All the specimens collected were males, and they were found in only one habitat - terrace slope with late snow melt.

Oreonetides vaginatus (Thorell, 1872)

COMMENTS. This species has a circum-Holarctic range and had previously been recorded from Koryakia. This species was found in high numbers, but only in the habitats with late snow melt.

Oryphantes bipilis (Kulczyński, 1885)

COMMENTS. This species has an east Siberian range. It had previously been recorded from Koryakia. This species was found in high numbers, but only in the habitats with late snow melt.

Pelecopsis mengei (Simon, 1884)**

COMMENTS. Although this species has a circumHolarctic range it was hitherto unknown from Koryakia and Kamchatka.

Phlattothrata parva (Kulczyński, 1926)

COMMENTS. This species has an east Siberian west Nearctic range. It had previously been recorded from Koryakia. This species was found in high numbers, but only in one habitat - terrace slope with late snow melt.

Porrhomma montanum Jackson, 1913

COMMENTS. This species has a Palaearctic range and had previously been recorded from western Koryakia.

Praestigia kulczynskii Eskov, 1979

COMMENTS. This species has a Siberio-Nearctic range and had previously been recorded from Koryakia.

Savignya birostra (Chamberlin et Ivie, 1947)*

COMMENTS. This species has an east Siberio - west Nearctic range. It had previously been recorded from Kamchatka, but was hitherto unknown from Koryakia.

Stemonyphantes sibiricus (Grube, 1861)

COMMENTS. This species has a Siberian range and had previously been recorded from Koryakia.

Styloctetor lehtineni Marusik et Tanasevitch, 1998**

COMMENTS. This species has a Siberian range. It was hitherto unknown from Koryakia and Kamchatka. 
Our find represents the easternmost locality record of its known distribution range.

Tenuiphantes mengei (Kulczyński, 1887)*

COMMENTS. This species has a trans-Palaearctic range. It had previously been recorded from Kamchatka, but was hitherto unknown from Koryakia.

Tmeticus tolli Kulczyński, 1908*

COMMENTS. This species has a Siberian range and had previously been recorded from Kamchatka, but was hitherto unknown from Koryakia.

Walckenaeria cuspidata Blackwall, 1833

COMMENTS. This species has a circum-Holarctic range and had previously been recorded from western Koryakia.

Walckenaeria karpinskii (O.Pickard-Cambridge, 1873)

COMMENTS. The species has a circum-Holarctic range and had previously been recorded from western Koryakia.

Wubanoides fissus (Kulczyński, 1926)*

COMMENTS. Although this species was described from Kamchatka and is rather common in east Siberia it was hitherto unknown from Koryakia.

Family Lycosidae (5)

Alopecosa aculeata (Clerck, 1757)*

COMMENTS. This species has a circum-Holarctic range. It had previously been recorded from Kamchatka but was hitherto unknown from Koryakia.

Pardosa aff. prosaica Chamberlin et Ivie, 1947*

COMMENTS. This species had previously been recorded from Kamchatka (sub $P$. disjuncta Jackson, 1933 [Buchar, 1971]), but was hitherto unknown from Koryakia. It seems that the east Siberian populations of $P$. aff. prosaica are not conspecific with the west Nearctic $P$. prosaica. All specimens were found among pebbles on the seashore.

Pardosa atrata (Thorell, 1873)*

COMMENTS. This species has a trans-Palaearctic range. It had previously been recorded from Kamchatka but was hitherto unknown from Koryakia. Although it was found in several habitats (cf. Table 1), it was dominant only in the wet lake shore environment.

\section{Pardosa palustris (Linnaeus, 1758)*}

COMMENTS. This species has a trans-Palaearcticwest Nearctic range. It had previously been recorded from Kamchatka but was hitherto unknown from Koryakia. This species was found in all habitats except for pebbly beaches. In most of the habitats it is the most numerous species. The total number (312) of specimens of $P$. palustris was much higher than the numbers of all other species.
Pardosa riparia (C.L. Koch, 1847)

COMMENTS. This species has a trans-Palaearctic range and had previously been recorded from Koryakia. Karaginski Island is the northeasternmost locality in the its known distribution range. The easternmost locality for this species is on the Commander Islands.

Family Philodromidae (1)

Tibellus maritimus (Menge, 1875)

COMMENTS. This species has a circum-Holarctic range and had previously been recorded from Koryakia.

Family Salticidae (1)

Sitticus floricola (C.L. Koch, 1837)**

COMMENTS. This species has a trans-Palaearctic range and was hitherto unknown from both Koryakia and Kamchatka. Our find represents the northeasternmost record of its known distribution range. S. floricola was previously known to occur east of Magadan Area only [Logunov \& Marusik, 2000].

Family Tetragnathidae (1)

Tetragnatha extensa (Linnaeus, 1758)

COMMENTS. This circum-Holarctic species had previously been recorded from western Koryakia [Marusik et al., 2010]. It was found in all habitats except for pebbly beaches, where the lack of herbs prohibits web construction. Most of the specimens were collected by sweep net sampling.

Family Theridiidae (2)

Enoplognatha caricis (Fickert, 1876)

COMMENTS. This circum-Holarctic species had previously been recorded from western Koryakia [Marusik et al., 2010], but only from juvenile specimens.

Robertus sp.

COMMENTS. The single juvenile specimen cannot be identified to species level. Four species of Robertus have previously been recorded from Koryakia [Marusik et al., 2010].

Family Thomisidae (2)

Ozyptila trux (Blackwall, 1846)**

COMMENTS. This species has a trans-Palaearctic range but was hithero unknown from Koryakia.

Xysticus britcheri Gertsch, 1934

COMMENTS. This species has an almost circumHolarctic range and had previously been recorded from both Kamchatka and Koryakia.

\section{Order OPILIONES}

Family Phalangiidae (1)

Mitopus morio (Farbricius, 1779)

COMMENTS. This species has a Holarctic range and had previously been recorded from western Kory- 
akia. It was found in all habitats (except pebbly beaches), M. morio was foundusually in high numbers.

\section{Discussion}

All 57 species treated in this paper are new to Karaginski Island. Of these, 26 spiders species found the island are new to Koryakia and 9 of them represent new records for Kamchatka Province. The total number of spider species found in Koryakia now totals 117.

The composition of the spider fauna on Karaginski Island is rather similar to faunas along the north coast of the Sea of Okhotsk. All species found on the island except for Sitticus floricola are known from the adjacent Magadan Area. Unlike in western Koryakia [cf. Marusik et al., 2010] no notable (extraordinary) species were found on the island.

Among 56 species of spiders belonging to 12 families, about 2/3 (34 species) of them belong to Linyphiidae. Such a high value of Linyphiidae is very characteristic for Hypoarctic faunas [Marusik, 2007, etc]. About half of the species reported from the island occur in the tundra landscape of Eurasia. However, true tundra species (those distributed in plain landscapes north of the taiga zone [Chernov \& Matveeva, 2002]) are absent from Karaginski Island. Most of the species just penetrate to the south-tundra landscapes and their main distribution range consists of the boreal or boreonemoral zones.

A high percentage of ecologically plastic boreal, boreo-nemoral and polyzonal species is a characteristic feature of the fauna of Kamchatka [Kurentsov, 1963]. In this respect, the latitudinal and longitudinal composition of the Karaginski Island spider fauna (and some insect groups [Khruleva \& Vinokurov, 2009; Barkalov et al., 2010]), is quite typical for the biota of the Kamchatka Peninsula. Only a few species have a limited distribution. Bathyphantes pogoinias is known from Kamchatka, north Sakhalin and the North Kuril Islands, northern Cisokhotia and Alaska. Oryphantes bipilis is restricted to Kamchatka and northern Cisokhotia, and Pardosa aff. prosaica is known to us from Magadan Area, northeastern Yakutia and Kamchatka. These three species can be considered as Beringian.

It is interesting that several polyzonal species are rather common in the studied area and that they occur in various habitats (Table 1). The same is true for the most numerous (in respect of number of specimens collected) species — the ground dwelling Pardosa palustris and grass dwelling Tetragnatha extensa.

The short collecting period and the fact that numerous species were represented by single specimens (15 species or $1 / 4$ of all species found) do not permit a detailed discussion of relative spatial distribution patterns. It is worth mentioning that the majority of species (26 including the harvestman) were collected in so-called tundra shrubby communities. It is worth mentioning that tundral communities as defined by botanists have no specific tundral spider species. Even pure boreal species are mostly absent from the island. In our opinion, the shrubby communities on the island appear tundral only in terms of their topography/morphology, and should be classified as such with a good degree of reservation.

ACKNOWLEDGEMENTS. We are deeply grateful to M.V. Berezin and E.Yu. Tkacheva, the expedition partners of OK, and also to the villagers of Ossora and Karaga (especially to V.V. Permyakov, V.A. Kudashev and to Mainovye's family) who helped with organization and assisted with collecting on Karaginski Island. We also thank Seppo Koponen (Turku) and Mikhail M. Omelko (Vladivostok) for valuable comments and help during the preparation of the manuscript.

This work was supported in part by the RFFI grants \#\# 09-04-01365, 11-04-01716-a, 11-04-00941, 12-04-00864-a and also by the Russian Academy Program «Biodiversity: inventory, function, protection».

\section{References}

Barkalov A.V., Mutin V.A., Khruleva O.A. 2010. Hover fly fauna (Diptera, Syrphidae) of Karaginski Island (the Bering Sea) // Zool. Zhurn. Vol.89. No.8. P.1016-1021 [English translation: Entomol. Rew. 2011. Vol.91. No.1. P.121-126].

Barkalov V.Yu., Kozhevnikov A.E., Kharkevich S.S. 1986. Vascular plants of Verkhoturova and Karaginski Islands (the Bering Sea) and protection of their genetic pool // Komarovsie chteniya. Vladivostok: DVNTs AN SSSR. Vyp.3. P.108-168 [in Russian]

Buchar J. 1971. Die Verwandtschaftsbeziehungen der Art Pardosa cincta (Kulczynski) (Araneae, Lycosidae) // Acta Univ. Carol. Biol. (1970). S.121-129.

Chernov Yu.I., Matveeva N.V. 2002. Landscape-zonal distribution of the Arctic biota species // Uspekhi sovremennoy biologii. Vol.122. No.1. P.26-45 [in Russian].

Kurentzov A.I. 1963. [The zoogeography of Kamchatka] // Fauna Kamchatki. M., L.: AN SSSR Publ. P.4-60 [in Russian].

Khruleva O.A., Vinokurov N.N. 2009. [Terrestrial bugs (Heteroptera) of the western coast of Karaginski Islands (Bering Sea)] // Sokhranenie bioraznoobrazyia Kamchatki i prilegaiyushchikh morey. Materials of X international scientific conference. Petropavlovsk-Kamchatsky. November 17-18 2009. P.138-141 [in Russian].

Logunov D.V., Marusik Yu.M. 2000. Catalogue of the jumping spiders of northern Asia (Arachnida, Araneae, Salticidae). Moscow: KMK Scientific Press Ltd. 299 pp.

Marusik Yu.M. 2007. [Spiders (Arachnida: Aranei) of the Asian part of Russia: taxonomy, fauna, zoogeography]. Autoreferate of Dr. Sci. Thesis. SPb.: SPbGU. 36 p. [in Russian].

Marusik Yu.M., Ryabukhin A.S., Kuzminykh G.V. 2010. New data on spiders and harvestmen (Arachnida: Aranei \& Opiliones) from Western Koryakia, Kamchatka Peninsula // Arthropoda Selecta.Vol.19. No.4. P. 227-236.

Mikhailov K.G. 2002. The spider fauna of Russia and other postSoviet republics: a 200 update // S. Toft \& N. Scharff (eds.). European Arachnology 2000. Proceedings of the 19th European Colloquium of Arachnology, Aarhus 17-22 July 2000. P.255-259.

Tanasevitch A.V. 2011. On linyphiid spiders (Araneae) from the Eastern and Central Mediterranean kept at the Muséum d'histoire naturelle, Geneva // Revue suisse de Zoologie. T.118. Fasc.1. P.49-91.

Responsible editor S. Koponen 